\title{
Fire Sales and the Financial Accelerator
}

Woon Gyu Choi and David Cook 


\title{
IMF Working Paper
}

\author{
IMF Institute
}

\section{Fire Sales and the Financial Accelerator}

\author{
Prepared by Woon Gyu Choi and David Cook ${ }^{1}$
}

Authorized for distribution by Ling Hui Tan

June 2010

\begin{abstract}
This Working Paper should not be reported as representing the views of the IMF.

The views expressed in this Working Paper are those of the author(s) and do not necessarily represent those of the IMF or IMF policy. Working Papers describe research in progress by the author(s) and are published to elicit comments and to further debate.

During periods of financial turmoil, increases in risk lead to higher default, foreclosure, and fire sales. This paper introduces a costly liquidation process for foreclosed collateral and endogenous recovery rates in a dynamic stochastic general equilibrium model of the financial accelerator. Consistent with empirical evidence, we find that recovery rates are pro-cyclical when collateral is costly to liquidate. Through links between recovery rates, risk premia, and default risk, the model generates an additional liquidity spiral, a feedback loop for the financial accelerator. We illustrate how collateral liquidation and monetary policy alter the impacts of a financial shock. We also show that a government subsidy on collateral liquidity and the endogenous accumulation of liquidity inventory help dampen the liquidity spiral by shoring up recovery rates.
\end{abstract}

JEL Classification Numbers:E27; E32; E58

Keywords: fire sales, financial accelerator, endogenous recovery rate, financial shock, liquidity spiral, collateral

Author's E-Mail Address:wchoi@imf.org; davcook@,ust.hk

\footnotetext{
${ }^{1}$ Woon Gyu Choi is a Senior Economist at the IMF Institute of the International Monetary Fund. David Cook is an Associate Professor of Economics at the Hong Kong University of Science and Technology. We thank Enrica Detragiache, Burkhard Drees, and Ling Hui Tan for useful comments and suggestions.
} 


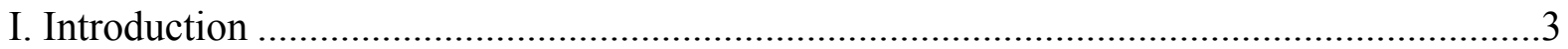

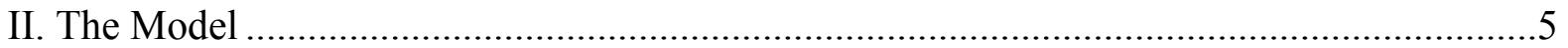

A. Competitive Firms........................................................................................... 5

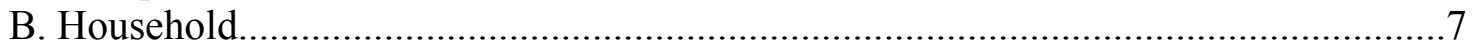

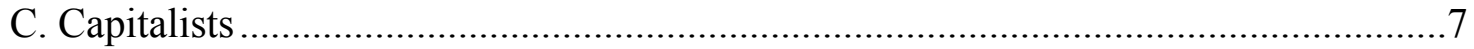

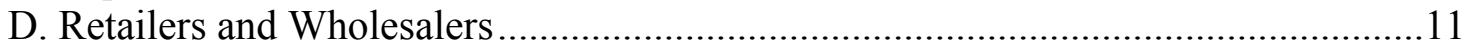

E. Central Bank and Shocks................................................................................... 11

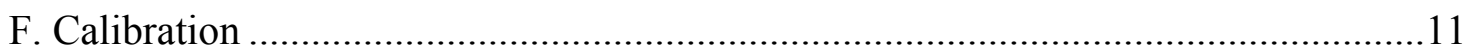

G. Discussion: Financial Shocks and Liquidity Spirals........................................ 12

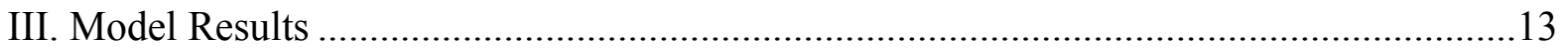

A. Impacts of Financial Shocks and the Role of Collateral Liquidity ..........................13

B. Interest Rate Policy Response: Concerns about Recession Risk ............................17

C. Government Subsidy for Collateral Liquidation ...............................................20

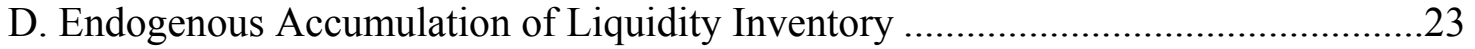

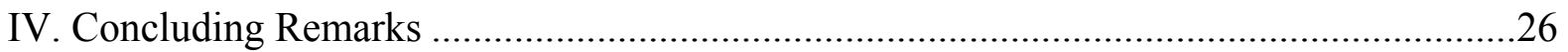

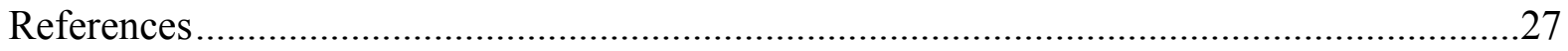

Figures

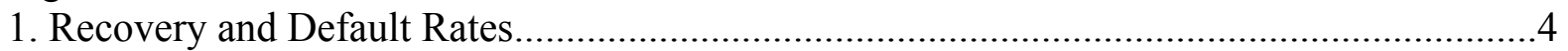

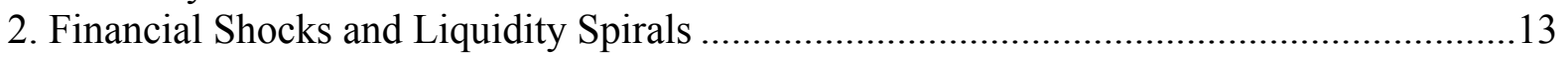

3. Responses to a Financial Uncertainty Shock: Liquid Model versus Illiquid Model .....15-16

4. Responses to a Financial Uncertainty Shock:

Pure Inflation Targeting versus Taylor Rule ............................................................18-19

5. Responses to a Financial Uncertainty Shock:

No Subsidy versus Subsidy for Collateral Liquidation.............................................21-22

6. Responses to a Financial Uncertainty Shock:

No Inventory versus Liquidity Inventory Collateral Liquidation 


\section{INTRODUCTION}

Just as default is an important, if regrettable, part of the lending process, so is the recovery of value from defaulted loans. Evidence suggests that recovery rates are volatile and vary with the credit cycle (see Bruche and Gonzalez-Aguado, 2006). In time periods when bank loan default rates are high, the degree of recovery on loans falls, exacerbating losses for banks. This paper examines the impact of endogenous fluctuations in recovery rates on the cyclical behavior of investment in a dynamic stochastic general equilibrium (DSGE) model with sticky prices and credit market imperfections that give rise to a financial accelerator (see Bernanke, Gertler, and Gilchrist, 1999; Carlstrom and Fuerst, 1997, 1998; Choi and Cook, 2004; and Cook, 2004).

Specifically, this paper shows how the channel of endogenous recovery rates amplifies the impacts of a financial shock on the economy. In financial accelerator models, debt with default risk is used to finance risky capital investment. In the case of default, creditors can foreclose on the assets at some liquidation cost. We present a model in which bottlenecks in the liquidating process of collateral reduce the ability of the economy to absorb foreclosed assets during times of widespread default. Endogenous recovery rates exacerbate the balance sheet effects of negative shocks, in contrast with existing models in which liquidation costs are modeled as a constant proportion of assets. If the liquidation costs of creditors rise in a downturn, lending terms for prospective borrowers will worsen. A central aspect of the financial accelerator model is the modeling of the risk premium on borrowing as a function of the probability of default. In a model in which recovery rates are time-variant, the risk of lending depends on not only the probability of default but also the fraction of collateral that will be received back in the case of default.

We follow Christiano, Motto, and Rostagno (2008) in modeling a financial crisis exogenously as a mean-preserving shock to the cross-sectional variance of idiosyncratic firm-level productivity. An increase in microeconomic randomness increases the probability of default and naturally raises the cost of borrowing. The contraction in investment acts as a negative demand shock. The rise in firm-level productivity volatility exogenously increases the probability of default. As defaults become more common across firms, the illiquidity of foreclosed assets reduces recovery rates, which, in turn, raise the risk premium. The greater risk premium negatively affects the aggregate economy and thus raises the probability of default. Endogenous liquidity of foreclosed properties then acts as a feedback loop - a liquidity spiral -which amplifies the financial accelerator.

Using a fairly standard DSGE with sticky prices, we examine the impact of a shock similar in size to that experienced by the financial system of the United States in 2008 . We show that the existence of the endogenous liquidity channel can sharply exacerbate the business cycle downturn beyond what might be expected from the standard financial accelerator model.

We calibrate the liquidity of the foreclosure process to match the volatility of recovery rates. To give an empirical idea of the degree of volatility of recovery rates, we collect default-related data from Federal Deposit Insurance Corporation's Historical Statistics on Banking. Figure 1 shows recovery rates, which are calculated as the accounting ratio of 
Figure 1. Recovery and Default Rates

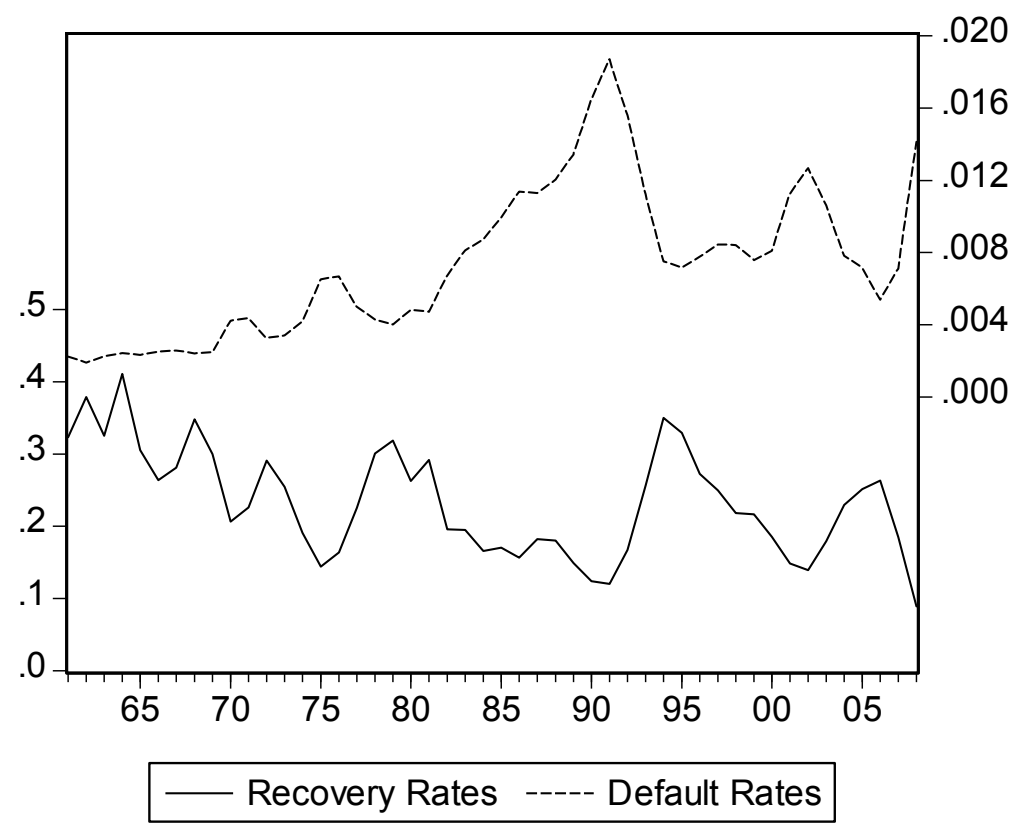

Notes: This figure depicts recovery and default rates for the period 1961-2008 using the data from FDIC's Historical Statistics on Banking. Recovery rates are the ratio of recoveries to gross charge-offs; and default rates are the ratio of gross charge-offs to gross loans.

recoveries to gross charge-offs for commercial banks for 1961-2008. Also shown are chargeoff rates or default rates, measured by the ratio of gross charge-offs to gross loans. Default rates, on average less than one percent per year, are extremely volatile with notable peaks during the recession of the early 1990s and 2000s. Recovery rates are equally volatile. About a quarter of loans are recovered on average, but recovery rates vary over time between 10 and 40 percents. Default rates edged up, and recovery rates edged down owing to the financial crisis starting from 2007. We detrend the natural logs of both series using a Hodrick-Prescott filter. In percentage terms, the standard deviation of recovery rates is 20.4 while that of default rates is 22.3 . Notably, recovery rates are highly negatively correlated with default rates: the correlation equals -0.89 .

The financial accelerator in investment is currently seen as an important part of investment dynamics at a business cycle frequency (see Bernanke, 2007). In the models of the financial accelerator based on monitoring costs (Williamson, 1987; and Bernanke and Gertler, 1989, 1990), borrowing is done through the optimal medium of risky debt (see Gale and Hellwig, 1985). ${ }^{2}$ The monitoring costs that drive these models can be viewed through

\footnotetext{
${ }^{2}$ Holmstrom and Tirole (1997) construct a model of bank liquidity based on an asymmetric information channel. Following Kiyotaki and Moore (1997), another strand of the literature on imperfect financial markets emphasizes the role of collateral constraints: for example, Chen (2001) examines the impact of asset price declines when the domestic banking system faces collateral constraints.
} 
the lens of liquidation costs. Shleifer and Vishny (1992) pioneer the modeling of liquidityconstrained collateral values. Substantial evidence suggests that recovery rates are reduced during periods of economic distress (see Altman and others, 2003). Asquith, Gertner, and Scharfstein (1994) find evidence that industry-level distress matters for recovery rates of individual firms. Acharya, Bharath, and Srinivasan (2007) find evidence that industrial firms have lower recovery rates in periods of economic distress, especially for firms with heavily industry-specific assets that entail higher liquidation costs. Bris, Welch, and Zhu (2003) find that, when the economy recovers, liquidated firms have worse recovery than other firms do.

An extreme form of financial distress is a financial crisis that triggers fire sales in financial markets. Krugman (1998) argues that, following financial crises, foreign investors are able to purchase troubled emerging market assets at fire sale prices. Aguiar and Gopinath (2005) provide evidence on post-crisis FDI flows. Acharya, Shin, and Yorulmazer (2007) suggest evidence that foreign investors take over failing firms by providing external liquidity through FDI inflows during financial crises.

Our findings shed light on interactions between macro-prudential surveillance and the characteristics of transmission mechanism in the face of financial shocks. In light of the 2007-2009 financial crisis, of crucial importance is to better understand the interactions between the financial sector and macroeconomic policies through macro-prudential surveillance (for example, Brunnermeier and others, 2009; and Bank of England, 2009) and to follow the resulting effects on the transmission mechanism of policies. Policymakers need to develop policy tools to dampen the amplification of both financial cycles and business cycles. This paper argues that the liquidation of collateral adds a liquidity spiral to the financial accelerator that is responsible for the amplification of investment fluctuations upon a financial shock. We show how monetary policy can dampen the impacts of the financial shock. Further, we show that a government subsidy on collateral liquidity and the endogenous accumulation of liquidity inventory help dampen the liquidity spiral by shoring up recovery rates.

\section{THE MOdeL}

\section{A. Competitive Firms}

Competitive firms comprise three types of representative, price-taking producers: output producers, liquidators, and capital producers.

1. Output Producers

A firm produces output goods using the Cobb-Douglas technology with constant returns to scale:

$$
Y_{t}=A_{t} K_{t}^{\theta} H_{t}^{1-\theta},
$$


where $K_{t}$ is installed capital and $H_{t}$ is labor. Output producers sell goods at a competitive price, $M C_{\mathrm{t}}$, to wholesale distributors. The producers rent labor at wage rate, $W_{t}$, and capital at rental rate, $R K_{t}$. The profit maximization conditions are:

$$
W_{t}=(1-\theta) \cdot M C_{t} \cdot \frac{Y_{t}}{H_{t}}, \quad R K_{t}=\theta \cdot M C_{t} \cdot \frac{Y_{t}}{K_{t}}
$$

\section{Liquidators}

Foreclosing on assets requires a certain amount of liquidity. Liquidators convert retail goods into marketable assets or liquidity in the form of goods using a technology with diminishing returns to scale. Thus, the cost of foreclosure will rise with the aggregate level of foreclosures. The liquidity provided is

$$
L Q_{t}=Z\left(N_{t}\right)^{\alpha}
$$

where $N_{t}$ is the quantity of final goods used for liquidation. The price level of the final good is $P_{t}$. The price of liquidity services per liquidity unit is $F_{t}$. Profits of liquidity service providers are:

$$
F_{t} \cdot Z\left(N_{t}\right)^{\alpha}-P_{t} N_{t}
$$

The first-order condition for the liquidators' maximization problem is:

$$
\frac{F_{t}}{P_{t}} \cdot \alpha Z\left(N_{t}\right)^{\alpha-1}=\frac{F_{t}}{P_{t}} \cdot \alpha \frac{L Q_{t}}{N_{t}}=1
$$

\section{Capital Construction}

Capital builders combine new investment and existing capital for the purpose of building capital for the future. New investment is combined with old capital net of depreciation to install the capital stock of the next period:

$$
K_{t+1}=(1-\delta) K_{t}+I_{t}
$$

Investment is purchased at price $P_{t}$, and existing capital is purchased at $Q_{t}$. Installed capital is sold for price $P_{t}^{K}$ in competitive markets. Profit maximization of capital builders implies:

$$
P_{t}=P_{t}^{K}, \quad Q_{t}=P_{t}^{K} \cdot(1-\delta)
$$




\section{B. Household}

Felicity increases with consumption, $C_{t}$, and decreases with market labor, $H_{t}$, as in Greenwood, Hercowitz, and Huffman (1988). A representative household maximizes the discounted sum of expected felicity:

$$
\underset{\{C, H, M\}}{\operatorname{Max}} \sum_{j=t}^{\infty} \beta^{j-t} \cdot\left\{\ln \left(C_{t}-\frac{\Gamma}{1+\psi} H_{t}^{1+\psi}\right)\right\} .
$$

The household earns money income by working at wage, $W_{t}$, and is paid lump-sum profits, $\Pi_{t}$, and pays a lump-sum fiscal tax, $T A X_{t}$. The budget constraint allows purchases of a riskfree bond issued by capitalists:

$$
B_{t}=W_{t} H_{t}+\Pi_{t}+\left(1+i_{t-1}\right) B_{t-1}-C_{t}-T A X_{t}
$$

The first-order conditions are:

$$
\begin{gathered}
\Gamma H_{t}^{\psi}=\frac{W_{t}}{P_{t}}, \\
1=E_{t}\left[\beta \cdot\left(1+i_{t}\right) \cdot \frac{\Omega_{t+1}}{\Omega_{t}}\right], \quad \Omega_{t} P_{t} \equiv \frac{1}{C_{t}-\frac{\Gamma}{1+\psi} H_{t}^{1+\psi}} .
\end{gathered}
$$

\section{Capitalists}

\section{Individual Entrepreneurs' Problem}

There is a unit range of entrepreneurs (capitalists), indexed by $l$. Capitalists are endowed with a stochastic technology that allows them to store capital across time. If $k^{l}$ is stored at time $t$, the capitalist will have $\omega^{l} k^{l}$ at time $t+1$. Stochastic technology, $\omega^{l}$, is independently distributed (across capitalists and time) with a log normal cumulative distribution function, $\Phi_{t}\left(\omega^{l}\right)$ with a mean of 1 . Potentially, the distribution may change from period to period according to a stochastic process. The capitalists begin with net worth, $n w^{l}$, and borrow, $b_{t}^{l}$, from households to finance the purchase of capital:

$$
b_{t}^{l}=p_{t}^{K} k_{t+1}^{l}-n w_{t}^{l}
$$

A solvent entrepreneur can earn a pay-off by renting capital to output producers and by selling capital back to capital builders at price $Q_{t}$. Define the nominal pay-off as:

$P A Y_{t}=Q_{t}+R_{t}$. The financial contract requires the capitalist to pay off their debt at an interest rate, $i^{r p}$, to the creditor; if they are unable to pay off, they turn over all capital to the creditor. The minimum level of idiosyncratic technology that will allow the entrepreneur to pay off their debt is given by: 


$$
\varpi_{t+1}^{l} \equiv \frac{\left(1+i_{t}^{r p}\right) \cdot b_{t}^{l}}{P A Y_{t+1} k_{t+1}^{l}}
$$

If the capitalist has a technology outcome less than $\varpi_{t+1}^{l}$, the creditor forecloses. To foreclose, the creditor must purchase a quantity of foreclosure services equal to a fraction of the capital stock, $v \cdot \varpi_{t+1}^{l} \cdot k_{t+1}^{l}$, at price $F_{t+1}$.

Assume that the financial contract chooses $\varpi_{t+1}^{l}$ and $k_{t+1}^{l}$ to maximize the expected payoff to the capitalists subject to bond holders receiving a payoff equal to the risk-free interest rate. The capitalists earn zero if they default, so the expected payoff is the product of the probability of no default and the conditional expected revenue if there is no default minus the interest paid to creditors. Thus the expected payoff to the capitalists is given by

$$
\begin{aligned}
& f\left(\varpi_{t+1}^{l}\right) P A Y_{t} k_{t+1}^{l} \\
& \text { with } f\left(\varpi_{t+1}^{l}\right) \equiv \int_{\varpi_{t+1}}^{\infty} \omega_{t+1} d \Phi-\varpi_{t+1}\left[1-\Phi\left(\varpi_{t+1}\right)\right]
\end{aligned}
$$

The expected payoff to the creditors is the recovery value adjusted for the probability of default plus the earned interest adjusted for the probability of default. Thus the constraint associated with the expected payoff to the creditors is given by

$$
\begin{aligned}
& g\left(\varpi_{t+1}^{l}, \mu_{t+1}\right) P A Y_{t}^{1} k_{t+1}^{l}=\left(1+i_{t}\right)\left[P_{t}^{K} k_{t+1}^{l}-n w_{t}^{l}\right] \\
& \text { with } g\left(\varpi_{t+1}^{l}, \mu_{t+1}\right) \equiv\left(1-\mu_{t+1}\right) \int_{0}^{\varpi_{t+1}} \omega_{t+1} d \Phi+\varpi_{t+1}\left[1-\Phi\left(\varpi_{t+1}\right)\right]
\end{aligned}
$$

where $\mu_{t+1} \equiv \frac{F_{t+1}}{P A Y_{t+1}} \cdot v$. The debt contract maximizes the payoff to the entrepreneurs subject to the creditors receiving a payoff equal to the risk-free interest rate:

$$
\begin{aligned}
\underset{\left\{\varpi_{t+1}^{l}, k_{t+1}^{l}\right\}}{\operatorname{Max}} & f\left(\varpi_{t+1}^{l}\right) P A Y_{t} k_{t+1}^{l} \\
& \text { s.t. } g\left(\varpi_{t+1}^{l}, \mu_{t+1}\right) P A Y_{t}^{1} k_{t+1}^{l}=\left(1+i_{t}\right)\left[P_{t}^{K} k_{t+1}^{l}-n w_{t}^{l}\right] .
\end{aligned}
$$

The first-order conditions of the entrepreneur' maximization problem imply that the expected payoff per each unit of capital should cover the risk premium of the gross return on capital over the interest rate. The degree of leverage, common across firms, generates a common risk premium as a function of leverage and the time-varying recovery rate: 


$$
E_{t}\left[\frac{P A Y_{t+1}}{P_{t}^{K} \cdot \rho\left(\varpi_{t+1}, \mu_{t+1}\right)}\right]=1+i_{t}
$$

where the risk premium, $\rho(\bullet)$, is of the form:

$$
\rho\left(\varpi_{t+1}, \mu_{t+1}\right) \equiv\left[g\left(\varpi_{t+1}, \mu_{t+1}\right)-\frac{g_{1}\left(\varpi_{t+1}, \mu_{t+1}\right) \cdot f\left(\varpi_{t+1}\right)}{f^{\prime}\left(\varpi_{t+1}\right)}\right]^{-1} .
$$

At time $t+1$, the capitalist receive a payoff from each unit of capital they own.

A fraction $\lambda$ of entrepreneurs will die in every period and consume their net worth. The next period's net worth will be:

$$
n w_{t+1}^{l}=(1-\lambda) \cdot f\left(\varpi_{t+1}\right) P A Y_{t+1} k_{t+1}^{l} .
$$

\section{Aggregation}

Aggregating the budget constraint for the entrepreneurs is:

$$
B_{t}=P_{t}^{K} K_{t+1}-N W_{t} .
$$

The aggregate payoff to creditors is:

$$
g\left(\varpi_{t}, \mu_{t}\right) P A Y_{t}^{K} K_{t}=\left(1+i_{t-1}\right) \cdot B_{t-1} .
$$

The level of liquidators' output is:

$$
v \cdot K_{t} \int_{0}^{\sigma_{t}} \varpi_{t} d \Phi=L Q_{t}
$$

The net worth of entrepreneurs follows as:

$$
N W_{t}=(1-\lambda) \cdot f\left(\varpi_{t}\right) P A Y_{t} K_{t} .
$$

Consumption by entrepreneurs is:

$$
P_{t} \cdot C K_{t}=\lambda \cdot f\left(\varpi_{t}\right) P A Y_{t} K_{t} .
$$




\section{Retailers and Wholesalers}

Retail firms combine a unit measure of differentiated wholesale goods. The production function of the retail good is:

$$
Y_{t}=\left(\int y_{l, t}^{\phi} d l\right)^{\frac{1}{\phi}}
$$

The demand for each retail good $l$ is a function of its price, $p_{l, t}$, as implied by

$$
\frac{y_{l, t}^{\phi-1}}{Y_{t}^{\phi-1}}=\frac{p_{l, t}}{P_{t}}
$$

where the price index is given by

$$
P_{t}=\left(\int p_{l, t}^{\frac{\phi}{\phi-1}} d l\right)^{\frac{\phi-1}{\phi}}
$$

A wholesaler produces differentiated good $l$ with a one-for-one transformation of the production good. Therefore, the marginal cost of producing the wholesale good, $M C_{t}$, is the price of the production good. In each period, a fraction of wholesalers, $(1-\kappa)$, receives the opportunity to change their nominal price. Wholesalers are owned by the workers and maximize the discounted sum of profits. A firm with the opportunity to change its price will maximize the discounted sum of profits:

$$
\underset{\{p\}}{\operatorname{Max}} E_{t}\left[\sum_{j=t}^{\infty}(\kappa \beta)^{j-t} \Omega_{j}\left\{p_{l, t} y_{l, j}-M C_{j} y_{l, j}\right\}\right] .
$$

Given the demand for each good, (26), we can write (28) as

$$
\operatorname{Max}_{\{p\}} E_{t}\left[\sum_{j=t}^{\infty}(\kappa \beta)^{j-t} \Omega_{j} Y_{j} P_{j}^{\frac{1}{1-\phi}}\left\{p_{l, t}^{\frac{\phi}{1-\phi}}-M C_{j} p_{l, t}^{\frac{1}{1-\phi}}\right\}\right] .
$$

The optimal price is:

$$
p_{t}=\frac{1}{\phi} \frac{E_{t}\left[\sum_{j=t}^{\infty}(\kappa \beta)^{j-t} \cdot \Omega_{j} Y_{j} P_{j}^{\frac{1}{1-\phi}} \cdot M C_{j}\right]}{E_{t}\left[\sum_{j=t}^{\infty}(\kappa \beta)^{j-t} \cdot \Omega_{j} Y_{j} P_{j}^{\frac{1}{1-\phi}}\right]} .
$$


The price level evolves according to

$$
P_{t}^{\frac{\phi}{\phi-1}}=\kappa \cdot P_{t-1}^{\frac{\phi}{\phi-1}}+(1-\kappa) \cdot p_{t}^{\frac{\phi}{\phi-1}} .
$$

Using the Galí and Gertler (1999) and Sbordone (2002) technique, we can write that inflation, $\pi_{t} \equiv P_{t} / P_{t-1}$, follows a process in a linearized form:

$$
\pi_{t}=\frac{(1-\kappa)(1-\beta \kappa)}{\kappa} m c_{t}+\beta E_{t}\left[\pi_{t+1}\right]
$$

In equilibrium, output goods will be used for consumption by households, $C_{t}$, and consumption by entrepreneurs, $C K_{t}$, new investment by capital builders, $I_{t}$. Final output will also be used as an input, $N_{t}$, by liquidators:

$$
Y_{t}=C_{t}+C K_{t}+I_{t}+N_{t}
$$

\section{E. Central Bank and Shocks}

The central bank sets the interest rate, following a Taylor (1993) rule:

$$
i_{t}=i_{S S}+\tau_{\pi} \cdot\left(\pi_{t}-\pi_{S S}\right)+\tau_{Y} \cdot \frac{Y_{t}-Y_{S S}}{Y_{S S}} .
$$

Following Christiano, Motto, and Rostagno (2008), we assume that the distribution of an idiosyncratic financial technology shock in a given period is log-normal: $\log \omega_{t}=N\left(-\sigma_{t}, \sigma_{t}^{2}\right)$. The shock is subject to persistent fluctuations, following the process:

$$
\left(\frac{\sigma_{t+1}-\sigma}{\sigma}\right)=\rho_{\sigma} \cdot\left(\frac{\sigma_{t}-\sigma}{\sigma}\right)+\varepsilon_{t}^{\sigma} .
$$

Note that an i.i.d. shock, $\varepsilon_{t}^{\sigma}$, is realized at time $t$ and impacts the variance at time $t+1$.

\section{F. Calibration}

Many parameters of the model are standard in the dynamic general equilibrium literature. We set $\beta=0.99, \delta=0.025$, and $\theta=0.36$, as in Hansen (1985). We set $\Gamma$ so that $H=1 / 3$ in the steady state. Following Greenwood, Hercowitz, and Huffman (1988), the Frisch elasticity of labor supply is set at $1 / \psi=1.7$. The fraction of firms setting prices in each is set at a standard 
level: $\kappa=0.75$ (Galí and Gertler, 1999). We assume an activist monetary policy with $\tau_{\pi}=1.5$. The persistence of the financial technology shock is estimated to be $\rho_{\sigma}=0.95$.

A more involved process will be the construction of the financial problem. Normalizing the liquidation technology gives the steady-state price of liquidation services as: $\frac{F_{S S}}{P_{S S}}=1$. In a given year, the fraction of loans that are charged off is $\Phi\left(\varpi_{t}\right)=\int_{0}^{\sigma_{t}} d \Phi$. For U.S. commercial banks, annual gross charge-offs relative to total loans for 1961-2008 is on average 0.73 percent. The recovery rate of financial intermediaries in collecting on bad loans is:

$$
r r_{t}=\left(1-\mu_{t}\right) \frac{\int_{0}^{\sigma} \omega d \Phi}{\Phi\left(\varpi_{t}\right)} \cdot \frac{P A Y_{t} K_{t}}{B_{t-1}}
$$

The ratio of recoveries to gross charge-offs on U.S. commercial bank loans averages 23.4 percent for 1961-2008. The annualized return spread between BAA and 1-year government securities for the same period is on average 270 basis points. To match these outcomes with the steady state of our model, we set at $\sigma=0.368, \lambda=.0161$ and $\mu=0.59$. This generates steady-state values: $\Phi\left(\varpi_{S S}\right)=0.0018$ which annualizes to 0.72 percent; $R_{S S}=0.232$; and $\rho\left(\varpi_{S S}, \mu_{S S}\right)=1.00675$, indicating 270 basis points of risk premium per annum.

\section{G. Discussion: Financial Shocks and Liquidity Spirals}

Figure 2 illustrates intuitively the response of the economy to financial shocks. A large negative financial shock immediately raises default risk which calls for endogenous subsequent effects on recovery rates and risk premium. Illiquidity in the collateral repossession process plays a crucial role in the downward cycle. First, the rise in default risk can lead to repossession and sales of collateral. Since collateral markets are illiquid, increases in the aggregate default level raise the liquidation cost of collateral, which reduces recovery rates and increases the riskiness of lending at a given default rate. The resulting increase in risk premium on lending exacerbates the downturn in investment demand which will have disinflation effects. Second, the real price of capital goods will also decline with reduced investment demand, weakening corporate balance sheets. Third, entrepreneurs' debts are denominated in nominal terms; therefore, disinflation increases debt burdens and hurts their balance sheets - the debt deflation logic rooted in Irving Fisher (1933). ${ }^{3}$

\footnotetext{
3 The deflationary impact on balance sheets has been incorporated in recent studies including Mendoza and Smith (2006), and Durdu, Mendoza, and Terrones (2009).
} 
Figure 2. Financial Shocks and Liquidity Spirals

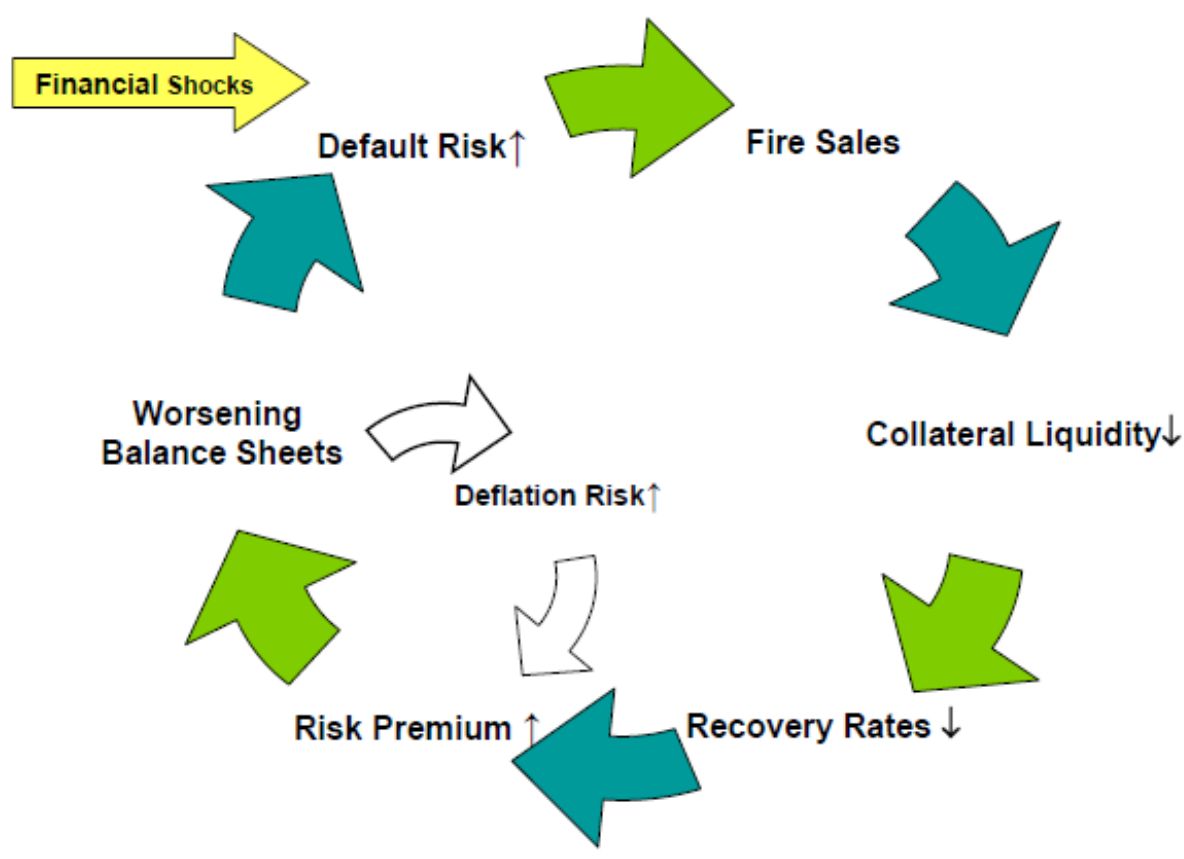

The deterioration in balance sheets will also make default more likely in the future, exacerbating the impact on the risk premium. Further rises in the risk premium intensify disinflation or the risk of the Fisherian debt deflation through balance sheet effects. Worsening balance sheets, in turn, increases the likelihood of default, which exacerbates illiquidity in collateral markets and drives recovery rates further down - a liquidity spiral.

\section{Model Results}

\section{A. Impacts of Financial Shocks and the Role of Collateral Liquidity}

We examine the response of the U.S. commercial banking sector to the financial crisis of 2008. We specify the size of the financial shock and the collateral liquidity parameter in equation (3), $\alpha$, to match two facts observed in the data upon this crisis: 1) a rise in default rates; and 2) a decline in recovery rates. The FDIC reports that default rates (calculated as the ratio of gross charge-offs to total loans) increased from 0.67 to 1.38 percent between 2007 and 2008. This change can be written as a 71.3 percent increase in default rates (in logarithmic terms). We consider a 5.5 percent shock to the idiosyncratic riskiness of lending, $\varepsilon_{1}^{\sigma}=0.055$, which generates a rise in default rates similar to those observed in the data. At the same time, recovery rates on loans (calculated as recoveries to gross charge-offs) fell from 17.62 to 8.62 percent. This can be written as a -71.5 percent logarithmic decrease. An aggregate increase in default rates makes the collateral of defaulting firms less liquid when $\alpha<1$. We calibrate the collateral liquidity parameter at $\alpha=0.6$ in our benchmark Illiquid model to generate a decline in recovery rates similar to that seen in the data. For 
comparison, we consider the Liquid case when $\alpha=1$ which leads to roughly constant recovery rates. We focus on the pure inflation targeting case, setting $\tau_{Y}=0$.

Figure 3.1 shows responses of financial variables to a financial crisis shock in the Liquid and Illiquid cases. Idiosyncratic volatility does not respond in the period of the shock, but expected volatility rises from period 2 and beyond. This has equilibrium effects which cause some firms to default immediately. However, the biggest impact on default rates is in the period after the shock, when idiosyncratic risk rises directly (see Panel B). During period 2, the default rate rises to a peak of about 70 percent (in log terms) in both cases. The rise in the default rate leads to a rise in the risk premium on lending, $\rho\left(\varpi_{t+1}, \mu_{t+1}\right)$, far more severely in the Illiquid case than the Liquid case due to the downward liquidity spiral (Panel A). In the Illiquid case, disposing collateral becomes more expensive when default rates start to rise and recovery rates sharply decline (Panels $\mathrm{B}$ and $\mathrm{C}$ ). Recovery rates fall by about 70 percent (by construction) in the Illiquid case, and remain virtually unchanged in the Liquid case. Falling recovery rates render lending more risky and, in the downward liquidity spiral, lead to more damage to firm balance sheets. Leverage, defined as $P_{t}^{K} K_{t+1} / N W_{t}$, rises in the Illiquid case by almost 1 percent while rising by less than 0.5 percent in the Liquid scenario (Panel D). The increase in leverage and the drop in recovery rates raise the risk premium by 0.7 percent (or about 280 annualized basis points) in the Illiquid case, compared to about 0.4 percent point in the Liquid case.

Figure 3.1 also shows the response of entrepreneurial consumption, $C K_{t}$, which is proportional to entrepreneurs' real net worth, $N W_{t} / P_{t}$ (Panel E). This falls approximately twice as much in the Illiquid case. The quantity of final goods used for liquidation, $N_{t}$, increases substantially after the shock: in period 2 when it reaches its peak, 60 percent above its steady state (Panel F). Note, however, that the size of $N$ in the steady state is less than 0.1 percent of overall output. Hence the cyclical rise in liquidity needs has little impact on the overall demand for output.

Figure 3.2 demonstrates how collateral liquidity affects the business cycle properties upon the financial shock. Household consumption's response depends on two opposing effects. First, reduced real interest rates have a positive effect on consumption through intertemporal substitution. Second, under Greenwood, Hercowitz, and Huffman's (1988) preferences, a decline in employment directly reduces the marginal utility of consumption. Intuitively, households substitute additional leisure for consumption. Moreover, given the persistent decline in capital, workers' wages and income should negatively affect permanent income. Consequently, in the Illiquid case, the negative effects of leisure substitution and lower permanent income dominate the positive effects of reduced real interest rates, leading to a persistent decrease in household consumption. In the Liquid case, the same happens only after a brief lag as the employment-income effects are outweighed initially by the interest rate effects (Panel A). Investment declines, more sharply with higher increases in the risk premium in the Illiquid case: the decline in investment is approximately 3 percent in the Liquid case and 5 percent in the Illiquid case (Panel B). 
Figure 3. Responses to a Financial Uncertainty Shock:

Liquid Model versus Illiquid Model

1. Financial Variables

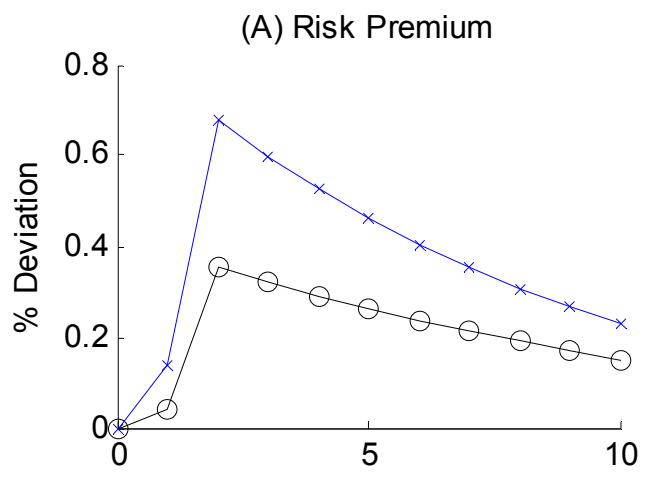

(C) Recovery Rate

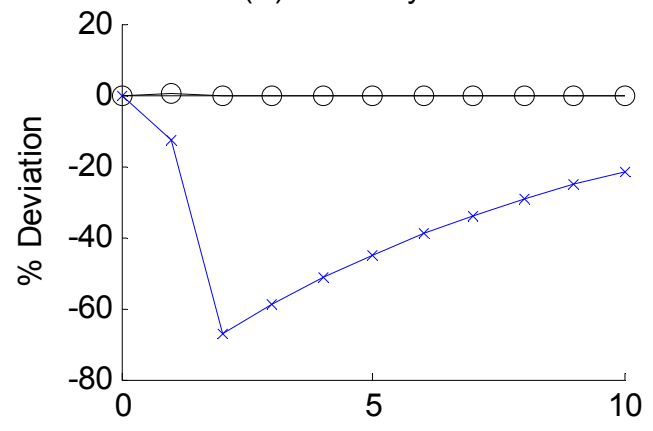

(E) Entrepreneurial Consumption

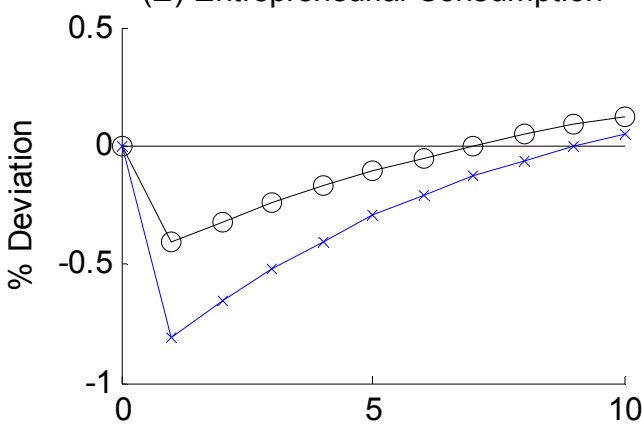

(B) Default Rate

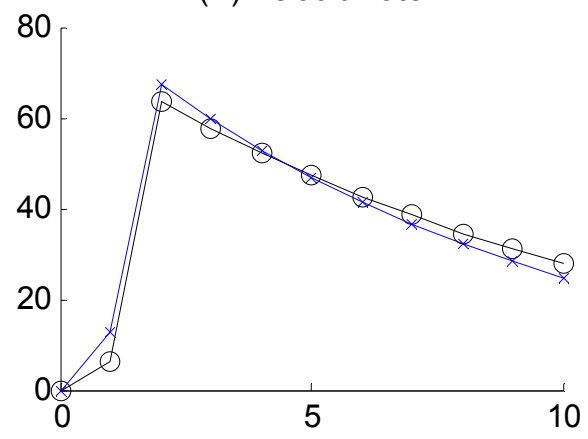

(D) Leverage

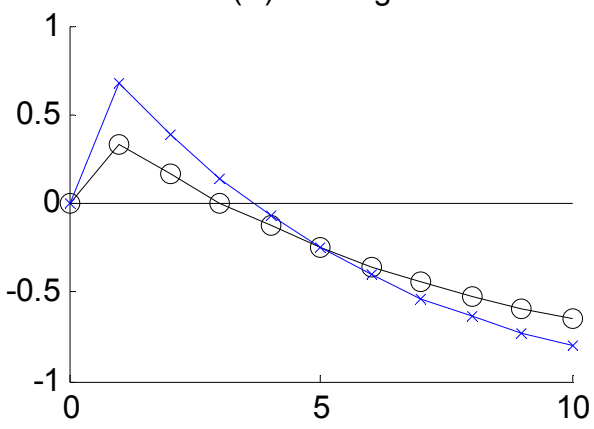

(F) Liquidity Demand

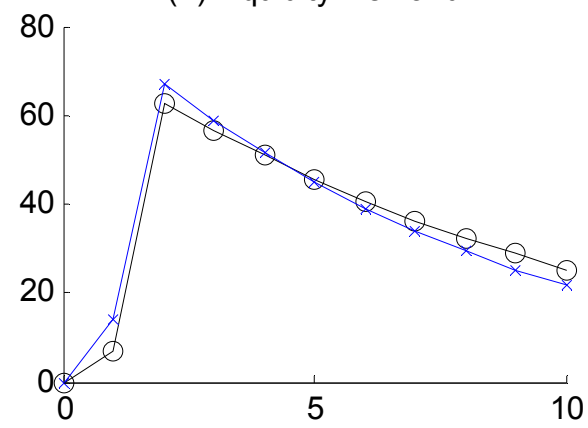

Liquid

Illiquid

Notes: This figure shows the benchmark model responses of financial variables associated with the financial problem of capitalists to a financial shock in period 1 under 1) the Liquid model in which default has non-increasing liquidation costs; and 2) the Illiquid model in which default has increasing liquidation costs. 


\section{Macroeconomic Aggregates}
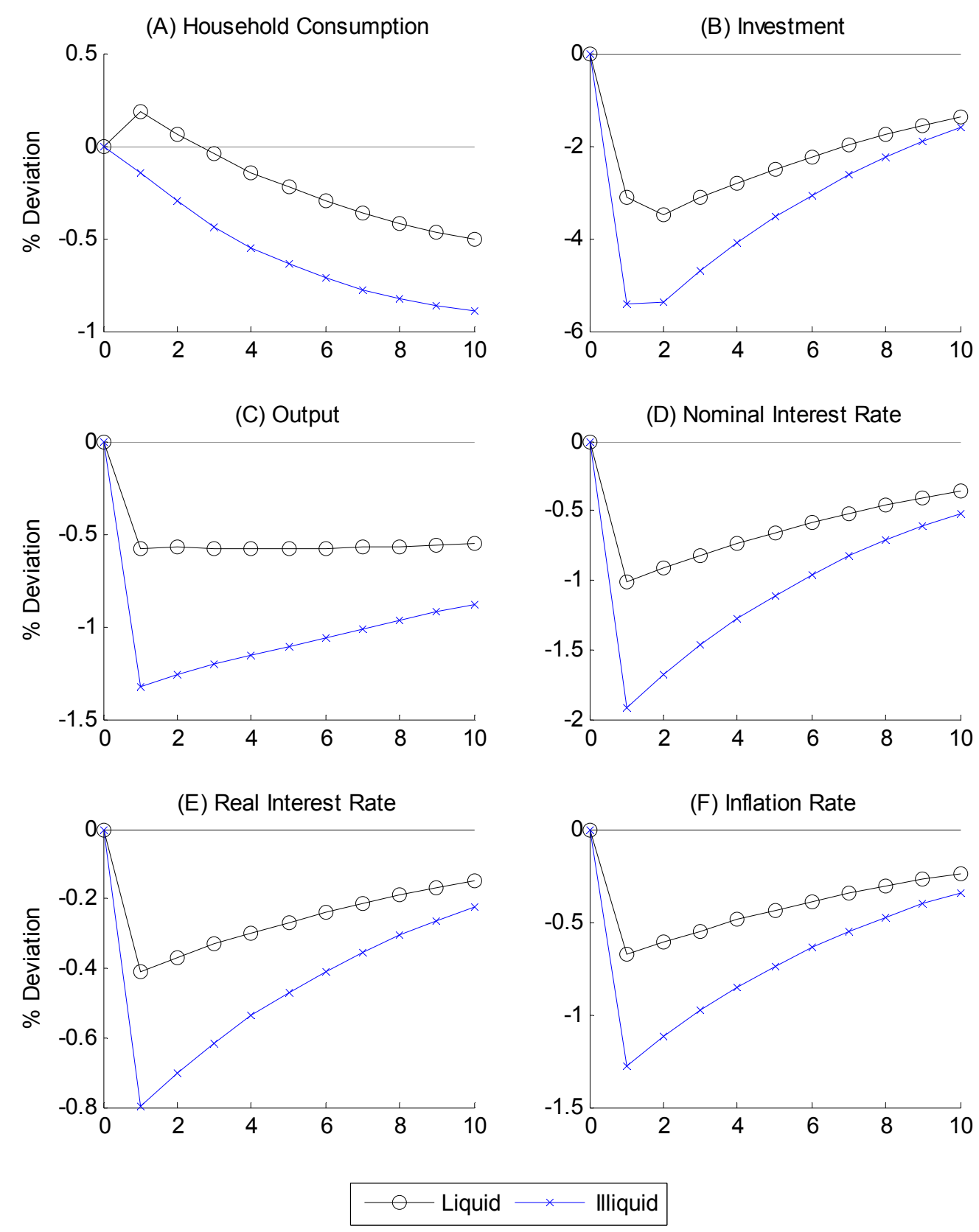

Notes: This figure shows the Benchmark model responses of macroeconomic aggregates to a financial uncertainty shock in period 1 under 1) the Liquid model in which default has non-increasing liquidation costs; and 2) the Illiquid model in which default has increasing liquidation costs. 
Given sticky prices, the declines in investment and household consumption, along with the decline in entrepreneurial consumption, have more severe negative impacts on output in the Illiquid case where output falls by 1.3 percent, compared to a 0.6 percent decline in the Liquid case (Panel C). Output declines initially owing to the reduced demand, and persistently as the financial accelerator prolongs the negative impact on capital investment.

The larger decline in demand in the Illiquid case generates a sharper disinflation. Inflation declines by 0.6 percent under the Liquid case but by nearly 1.3 percent under the Illiquid case (Panel F). The sharper disinflation in the Illiquid model generates sharper declines in nominal and real interest rates (Panels D and E).

\section{B. Interest Rate Policy Response: Concerns about Recession Risk}

In this section, we examine how monetary policy can be used to offset some of the impacts of the financial shock, considering a Taylor rule through which the central bank adjusts interest rates in response to both inflation and output. The interest rate rule is defined as $\tau_{\pi}=1.5$ and $\tau_{Y}=0.5$. We show the responses of the economy to a financial crisis shock of size $\varepsilon_{1}^{\sigma}=0.055$ in the Illiquid collateral scenario with $\alpha=0.6$. For comparison, we also show the response of the economy under pure inflation targeting with $\tau_{\pi}=1.5$ and $\tau_{Y}=0$, also with illiquid collateral.

Figure 4.2 suggests that monetary policy responding to output ameliorates the impact of the financial shock on the risk premium and, thus, the economy. As seen previously, the financial shock leads to a persistent output decline. In response, the Taylor rule induces a sharper and more persistent cut in both nominal and real interest rates, compared to pure inflation targeting (Panels D and E). Sharper decreases in real interest rates dampen the negative impact of the shock on investment and household consumption (Panels A and B). This less sharp drop in demand leads to a milder decline in output and milder disinflation (Panels $\mathrm{C}$ and F).

The monetary policy reaction to negative pressure on output indirectly counters deterioration in the financial sector, as shown in Figure 4.1. The milder disinflation under the Taylor rule dampens the persistent rise in the risk premium and reduces the adverse impact of the shock on entrepreneurs' balance sheets. The relatively limited damage to entrepreneurs' balance sheets somewhat ameliorates persistent rises in the risk premium and default rates, and persistent falls in recovery rates (Panels A-C). Under pure inflation targeting, entrepreneurs' consumption, proportional to net worth, falls sharply and persistently; and under the Taylor Rule, entrepreneurs' net worth and consumption fall by a smaller amount and recover rapidly, surpassing its steady-state level from 3 periods after the shock (Panel E). This implies mild and brief increases in the leverage of entrepreneurs above the steady state (Panel D) and less need for collateral liquidity (Panel F). However, the financial shock does increase the risk premium and reduce recovery rates under either monetary policy, and the effect of monetary policy on these factors is relatively weak. We also note that monetary policy reactions can be constrained by the zero bound on interest rates if the prevailing policy rate is very low. 
Figure 4. Responses to a Financial Uncertainty Shock:

Pure Inflation Targeting versus Taylor Rule

1. Financial Variables
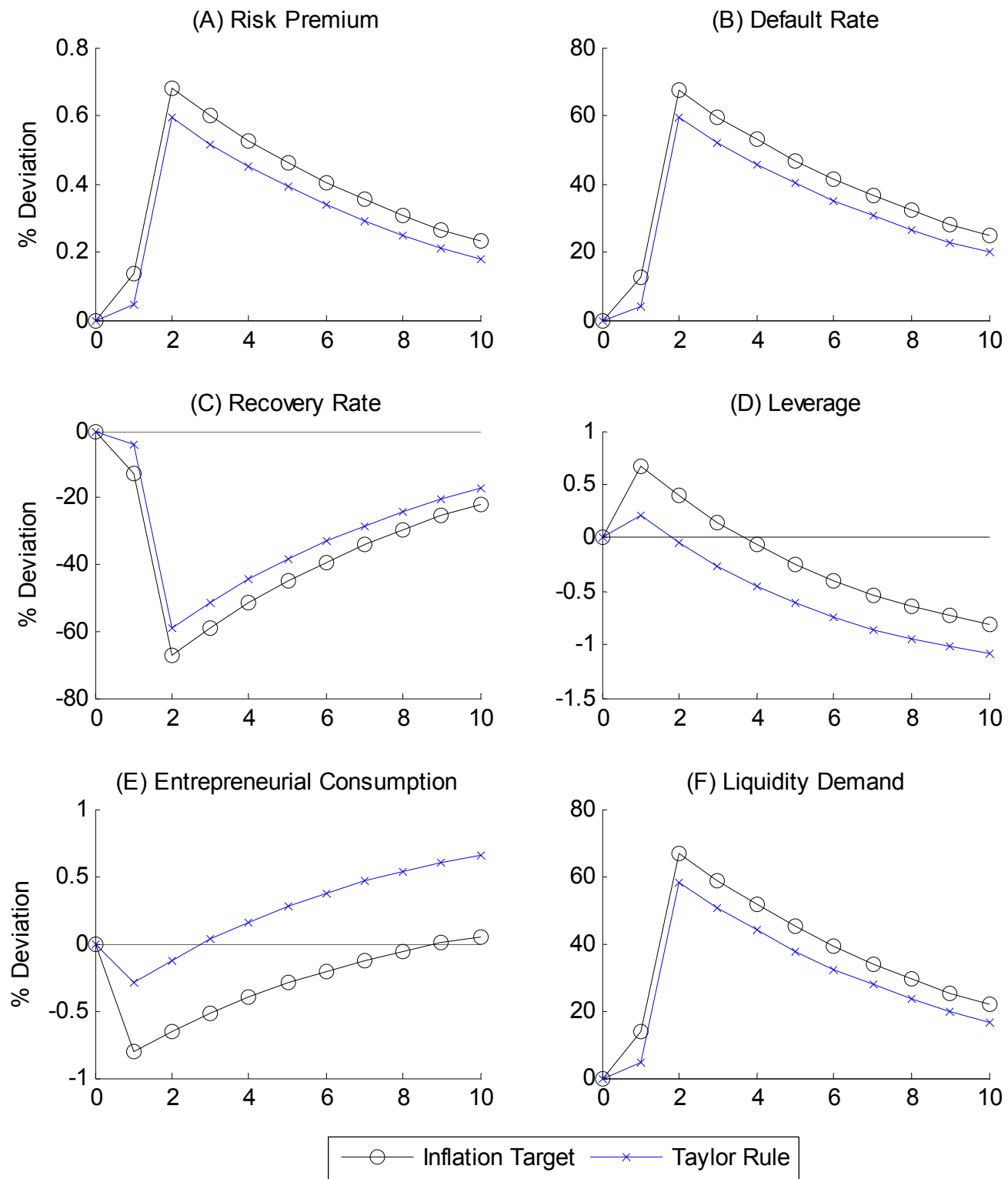

Notes: This figure shows the benchmark illiquidity model responses of financial variables to a financial uncertainty shock in period 1 under 1) pure inflation targeting; and 2) a Taylor rule. 


\section{Macroeconomic Aggregates}
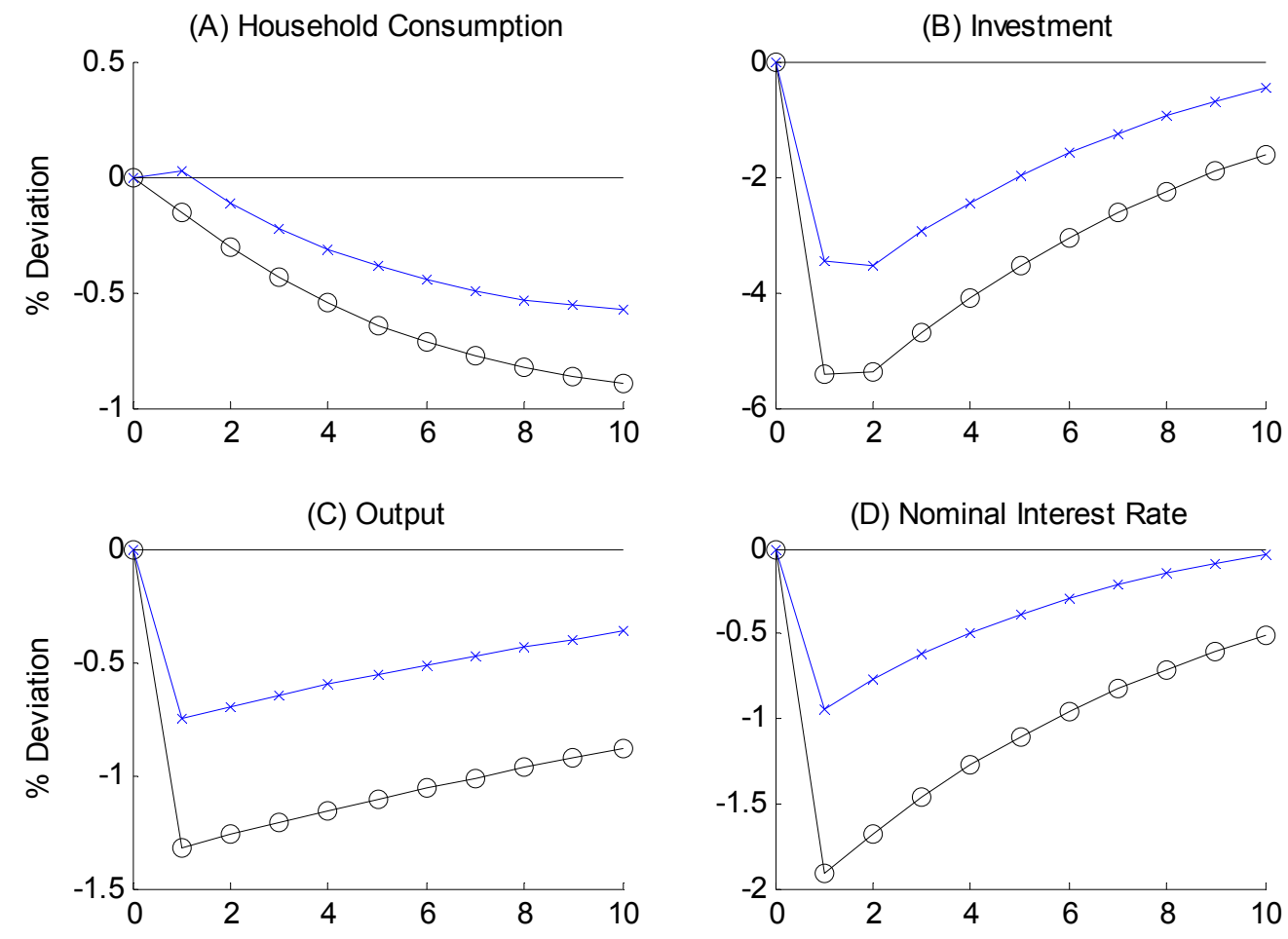

(D) Nominal Interest Rate

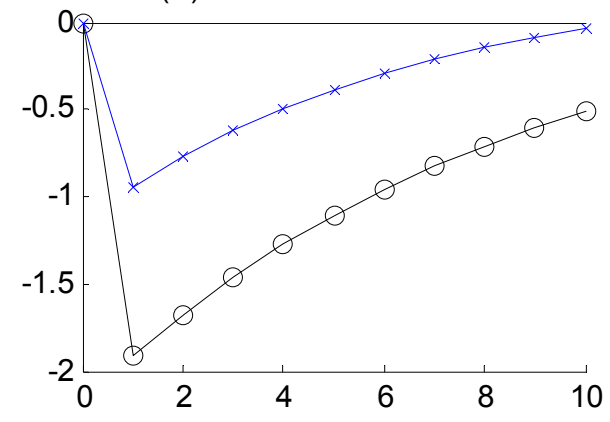

(E) Real Interest Rate

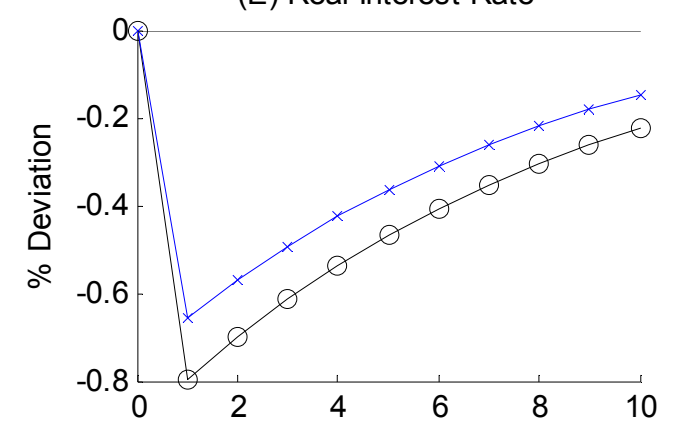

(F) Inflation Rate

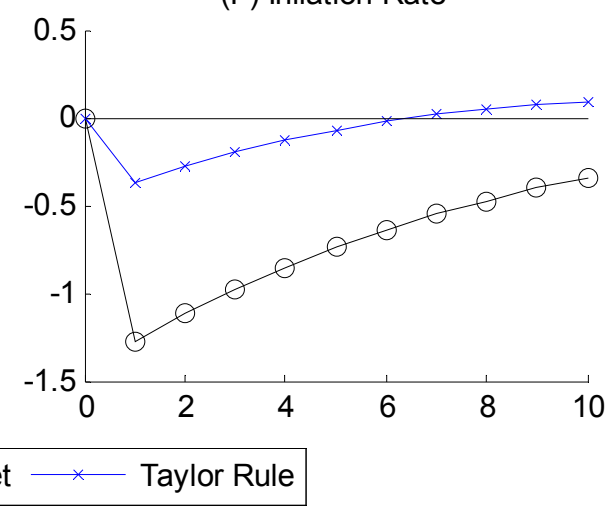

Notes: This figure shows the benchmark illiquidity model responses of macroeconomic aggregates to a financial uncertainty shock in period 1 under 1) pure inflation targeting; and 2) a Taylor rule. 


\section{Government Subsidy for Collateral Liquidation}

Consider if the government subsidizes liquidity for the financial system, financed by a lump-sum fiscal tax, during the financial crisis. Suppose that a subsidy, $s$, reduces the price of acquiring liquidity for the firm. We then write as: $\mu_{t+1}=\left(1-s_{t+1}\right) \cdot \frac{F_{t+1}}{P A Y_{t+1}} \cdot v$. We assume that the government sets this subsidy as:

$$
\frac{s_{t}-s_{s s}}{s_{s s}}=\Theta \cdot \frac{r p_{t}-r p_{s s}}{r p_{s s}}
$$

so that the government contribution to the liquidity of the financial market increases with the risk premium. For a Subsidy case, we set $s_{s s}=0.05$ without adjusting $\mu_{S S}$ (or the steady state in any way) and set $\Theta=2000$. The subsidy is financed by a lump-sum tax on households (who are Ricardian-equivalent). Since the government budget constraint requires the lumpsum tax to be equal to the subsidy that is small at steady state, changes in the subsidy or tax over business cycles are of second order in size in the household budget. This suggests that the subsidy to reduce liquidation costs has small income effects relative to its impacts through the financial accelerator on business cycle dynamics. Liquidation costs affect the economy by raising the cost of capital: especially near the steady state, investment demand is very sensitive to small changes in the cost of capital. Hence, the subsidy that offsets these small changes in the cost of capital can countervail strongly the adverse impact of a financial shock on aggregate demand.

Figure 5 shows the responses of the economy to the financial shock in the Subsidy case, along with the No Subsidy case $\left(s_{s s}=0\right.$ and $\left.\Theta=0\right)$. The financial impacts of the targeted subsidy are depicted by Figure 5.1. The financial shock increases the risk premium and default rate (Panels A and B). In the model without government support for the liquidation of collateral, the rise in default leads to a sharp decline in recovery rates. In the case where the government supports the liquidation of collateral, recovery rates remain fairly stable around the steady state (Panel C), while the demand for collateral liquidity is largely unaffected (Panel F). As a result, the increase in the risk premium is relatively limited, and the level of leverage and the reduction of entrepreneurial consumption through balance sheet effects are dampened (Panels D and E).

As shown in Figure 5.2, the impacts of the financial shock on the macroeconomy are substantially reduced under the government's support for collateral liquidation. The dampened increase in the risk premium results in more moderate decreases in investment, output, and household consumption (Panels A-C), accompanied by more moderate disinflation and smaller cuts in nominal and real interest rates (Panels D-F). 
Figure 5. Responses to a Financial Uncertainty Shock: No Subsidy versus Subsidy for Collateral Liquidation

1. Financial Variables
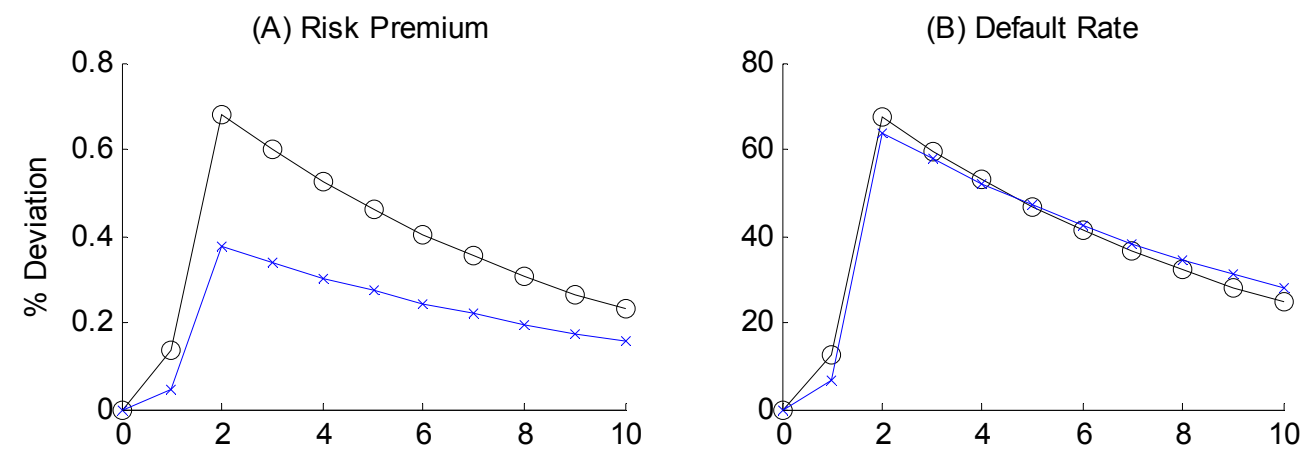

(C) Recovery Rate
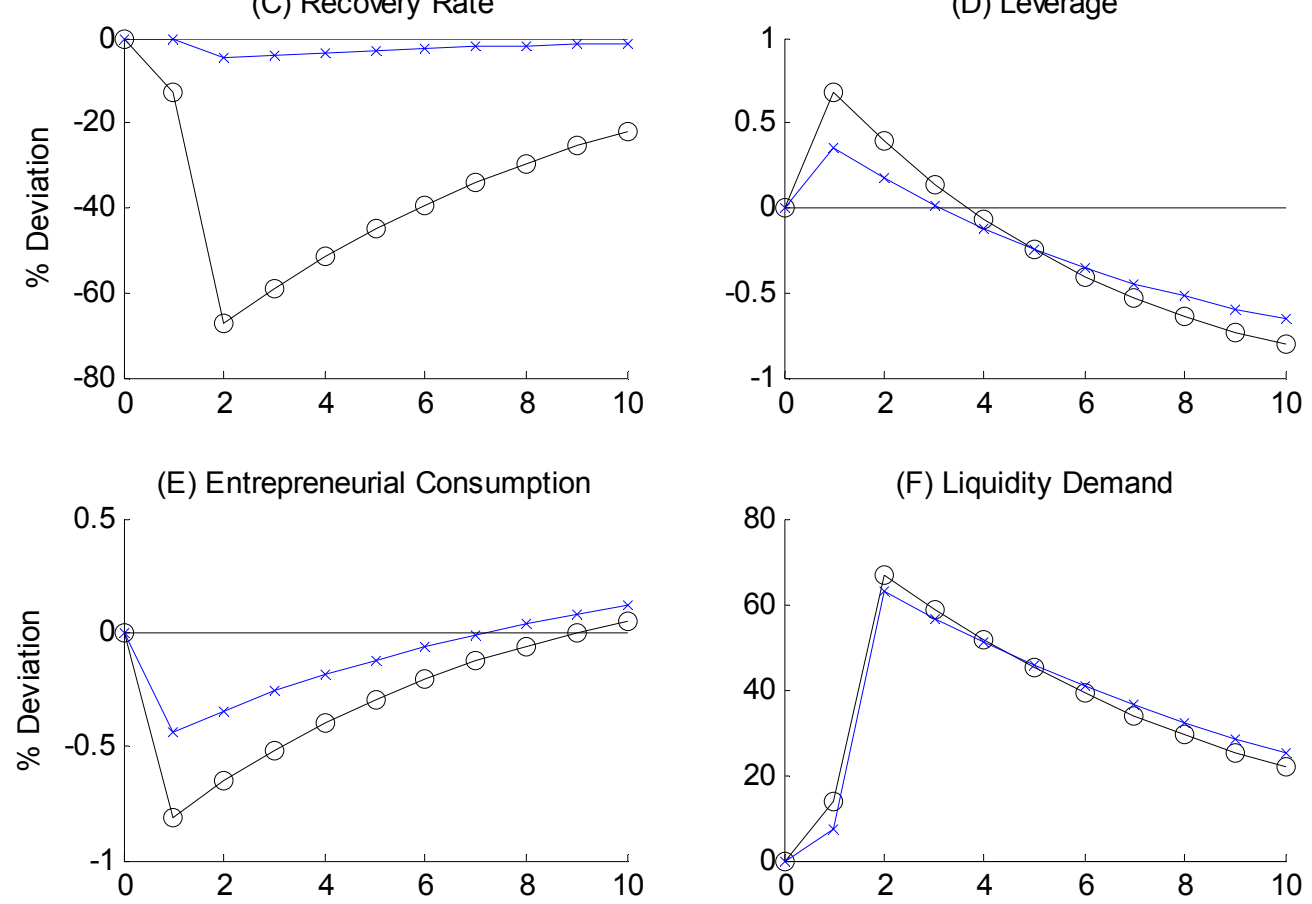

(F) Liquidity Demand

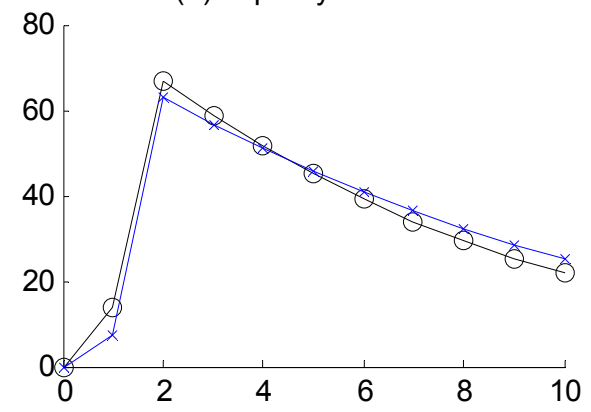

No Subsidy — Subsidy

Notes: This figure shows the benchmark illiquidity model responses of financial variables to a financial uncertainty shock in period 1 under 1) no subsidy to collateral prices; and 2) a subsidy to collateral prices. 


\section{Macroeconomic Aggregates}

(A) Household Consumption

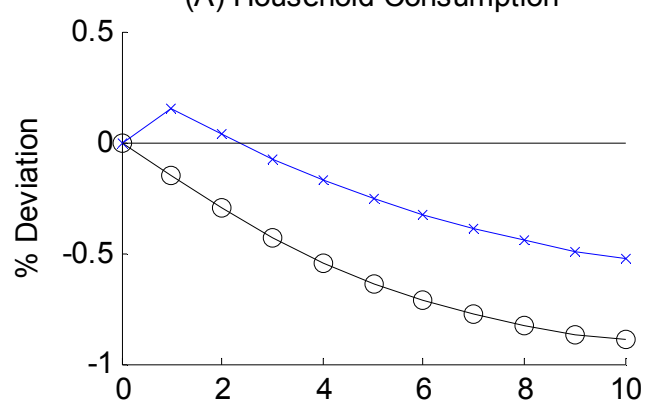

(C) Output

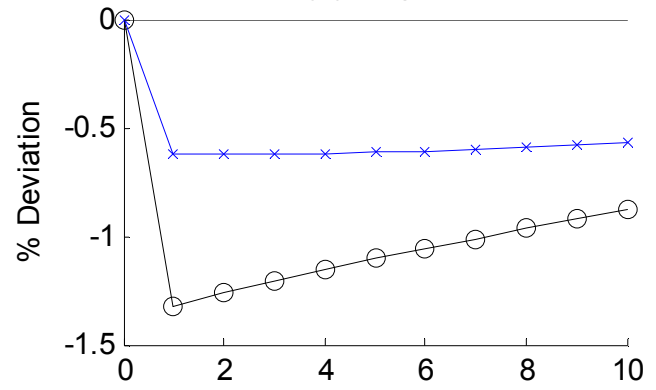

(E) Real Interest Rate

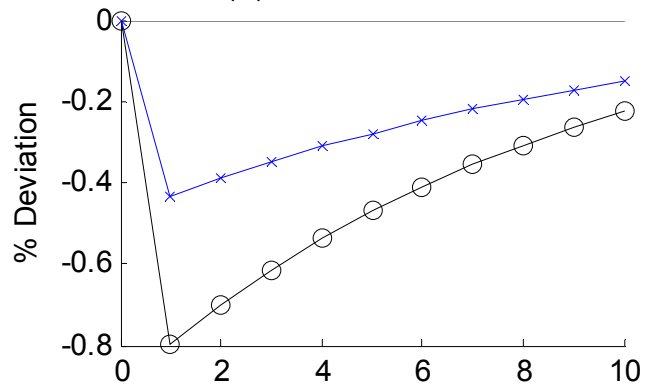

(B) Investment

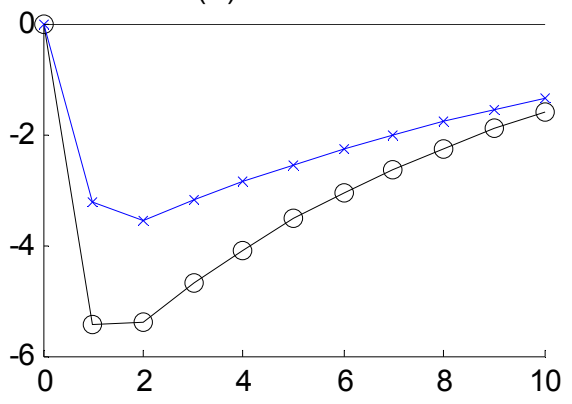

(D) Nominal Interest Rate

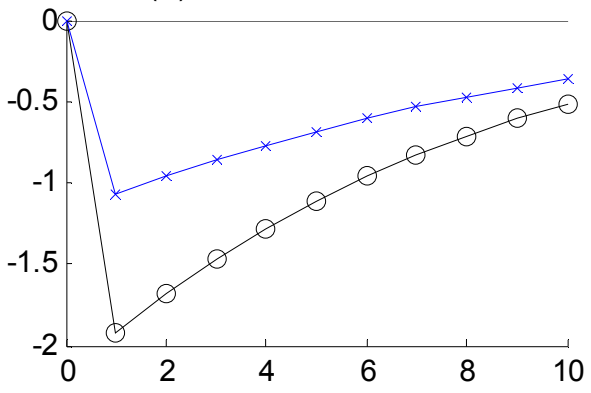

(F) Inflation Rate

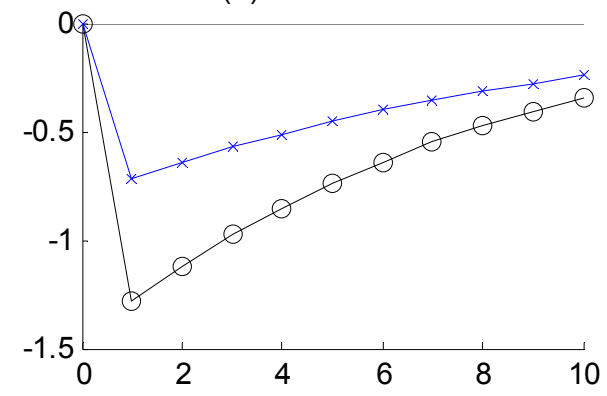

No Subsidy — Subsidy

Notes: This figure shows the benchmark illiquidity model responses of macroeconomic aggregates to a financial uncertainty shock in period 1 under 1) no subsidy to collateral prices; and 2) a subsidy to collateral prices. 


\section{Endogenous Accumulation of Liquidity Inventory}

We now examine a model in which liquidators can build up liquidity inventory as buffers against strains on liquidity in collateral markets, as opposed to the previous case where the liquidity availability to foreclosing creditors is static regardless of conditions in the economy. Liquidity inventory, in the form of output goods, promotes the provision of liquidity services in collateral markets:

$$
L Q_{t}=Z\left(N_{t}\right)^{\alpha}\left(V_{t}\right)^{1-\alpha}
$$

where $V_{t}$ is the liquidity inventory that is accumulated through the liquidator's investment, $L I$, by purchasing output goods:

$$
V_{t+1}=(1-\eta) \cdot V_{t}+L I_{t} .
$$

Optimal demand for the liquidity inventory is:

$$
\beta \cdot E_{t}\left[\Omega_{t+1}\left\{(1-\alpha) \frac{F_{t+1} L Q_{t+1}}{L I_{t+1}}+P_{t+1}(1-\eta)\right\}\right]=\Omega_{t} P_{t} .
$$

The equilibrium level of output becomes:

$$
Y_{t}=C_{t}+C K_{t}+I_{t}+N_{t}+L I_{t}
$$

Figure 6 shows model responses to the financial shock when the financial system can build up a liquidity inventory to handle the collateral repossession process. We compare the responses to the No Inventory case where no inventory is built up. Figure 6.1 suggests that the impacts on the financial sector appear similar to the case of the government subsidy case. The exception is that the endogenous liquidity buildup is reflected in reduced demand for collateral liquidity while ensuring recovery rates around the steady state. The rise in idiosyncratic risk leads to an increase in the default likelihood (Panel B). The expected rise in collateral liquidity needs (Panel F) calls for an increase in liquidity inventory, $V_{t}$, in the Liquidity Inventory case. The increase in liquidity inventory results in a minimal and temporary drop in recovery rates in the Liquidity Inventory case, compared to the large drop in the No Inventory case (Panel C). Naturally, the risk premium rises by substantially less in the Liquidity Inventory case than the benchmark case (Panel A).

The overall effect of the financial shock on the macroeconomy is less contractionary when the financial system is able to build a liquidity inventory, as shown in Figure 6.2. The buildup of liquidity inventory helps dampen the rise in the risk premium, resulting in reduced contractions in investment, consumption, and output (Panels $\mathrm{A}-\mathrm{C}$ ). As a result, the Liquidity Inventory case generates more moderate disinflation along with smaller cuts in nominal and real rates (Panels $\mathrm{D}-\mathrm{F})$. 
Figure 6. Responses to a Financial Uncertainty Shock:

No Inventory versus Liquidity Inventory

1. Financial Variables
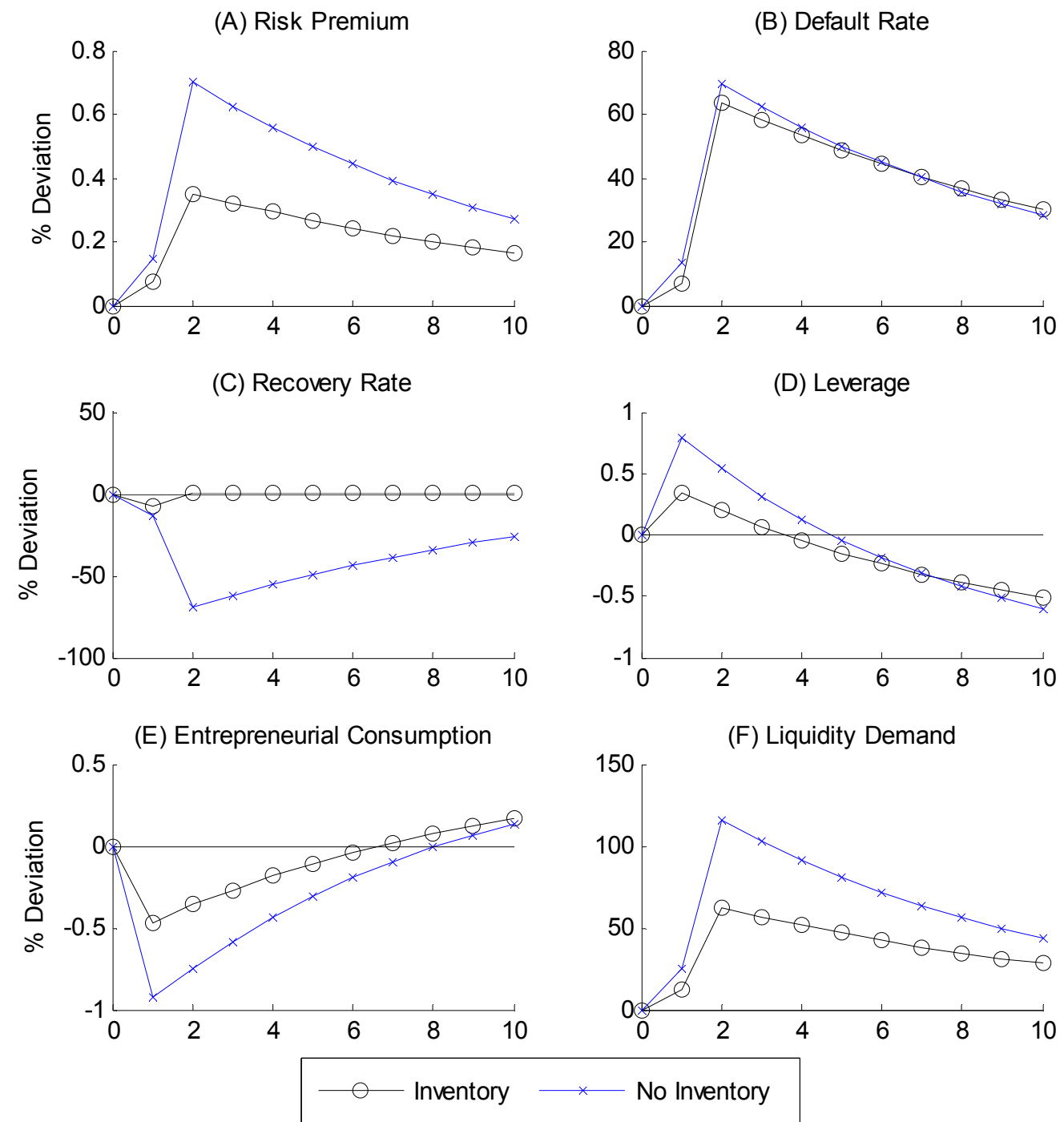

Notes: This figure shows the benchmark illiquidity model responses of financial variables to a financial uncertainty shock in period 1 in 1) the No Inventory case with no ability to accumulate liquidity inventory over time; and 2) the Liquidity Inventory model when liquidity inventory can be accumulated. 


\section{Macroeconomic Aggregates}
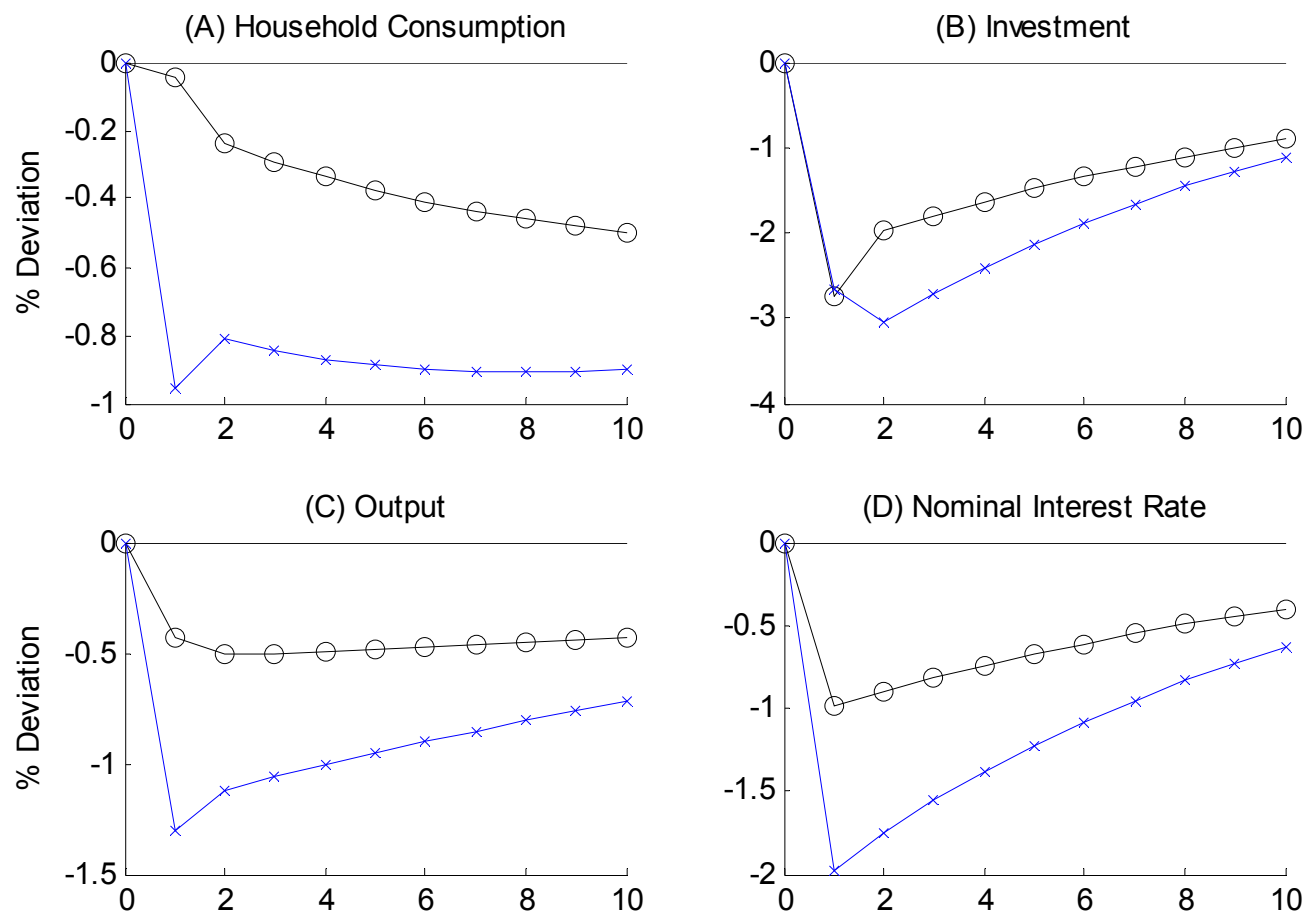

(D) Nominal Interest Rate
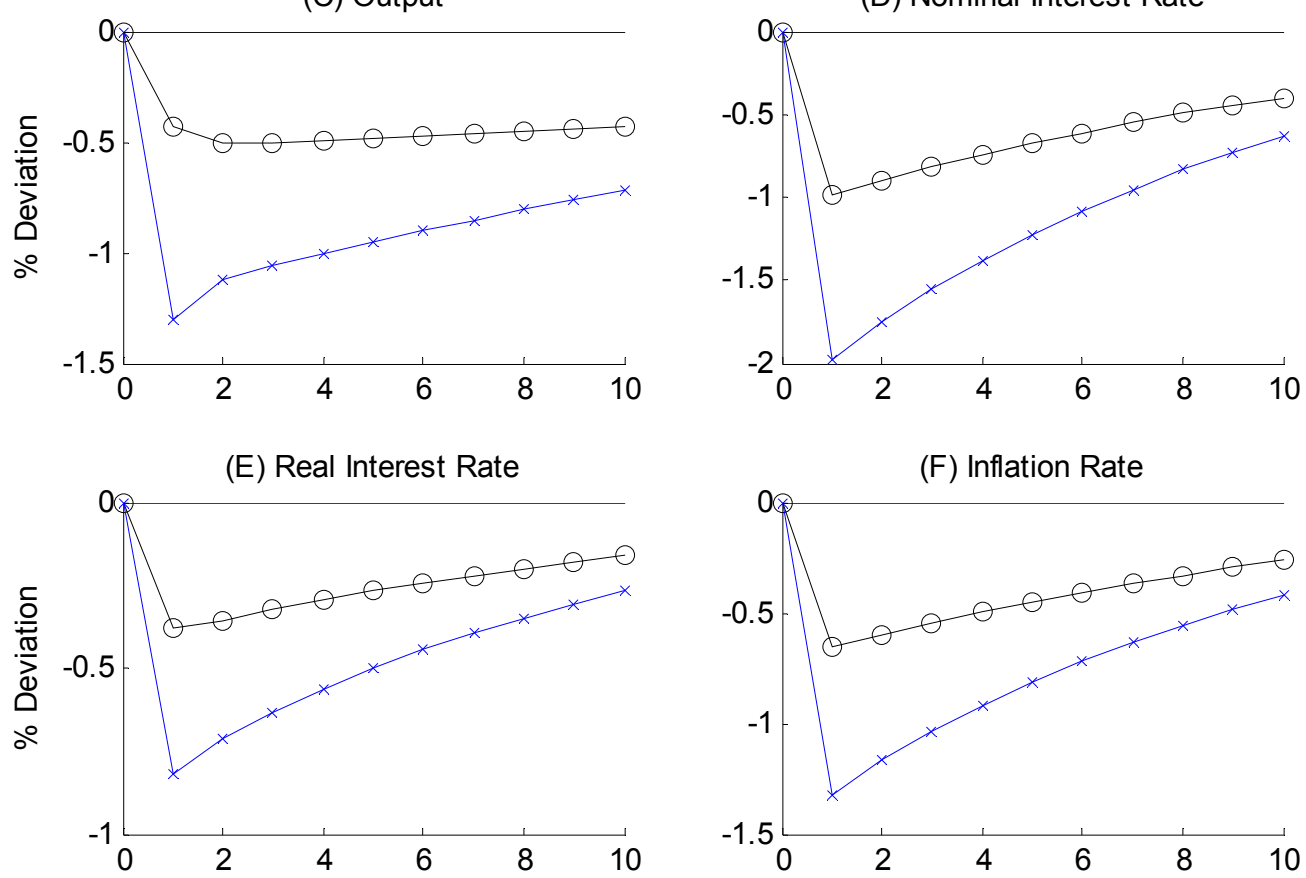

(F) Inflation Rate

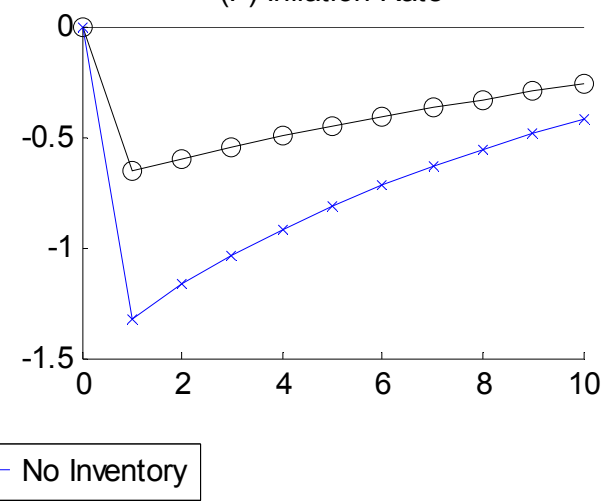

Notes: This figure shows the benchmark illiquidity model responses of macroeconomic aggregates to a financial uncertainty shock in period 1 in 1 ) the No Inventory case with no ability to accumulate liquidity inventory over time; and 2) the Liquidity Inventory model when liquidity inventory can be accumulated. 


\section{CONCLUding Remarks}

This paper focuses on the business cycle impact of endogenous fluctuations in recovery rates upon default. The resolution of defaulted loans relies upon the liquidity of the collateral market. A financial crisis, accompanied by a rise in default risk, inherently taxes the ability of the financial system to liquidate collateral. The increase in default risk causes an increase in risk premium and a fall in recovery rates, reducing liquidity in the collateral market, which, in turn, exacerbates the increase in risk premium.

Our model characterizes a certain type of liquidity spiral responsible for the amplification of a financial crisis. We suggest that endogenous responses of collateral liquidity, manifested by dynamic responses of recovery rates, provide an additional source of amplifying the financial accelerator. This mechanism generates a sharper disinflation process and reinforces the potential risk of debt deflation relative to standard financial accelerator models.

This paper demonstrates some potential policy responses to dampen the liquidity spiral. First, monetary policy clearly can play the role of moderating downturns in economic activities by lowering the policy rate unless the zero bound constraint on interest rates is binding. Second, direct subsidies which alleviate the loss of value of collateral can also ameliorate the negative business cycle impacts of the financial crisis. Third, endogenous liquidity inventory buildups help increase the resilience of the economy to a financial shock and promote inherent financial stability. As is well-known, interest rate policy has the obvious lower bound on the reduction of the nominal rate in the face of persistent financial shocks when the prevailing rate is already very low. We also note that government liquidity subsidies (for example, by shoring up funding liquidity) will require public resources and eventually be financed by government taxes. In contrast, the liquidity buildup by entrepreneurs can be supported by private resources on the basis of market signals. 


\section{References}

Acharya, Viral V., H.S. Shin, and T. Yorulmazer, 2007, "Fire Sale FDI," CEPR Discussion Papers, No. 6319.

Acharya, Viral V., S.T. Bharath, and A. Srinivasan, 2007, "Does Industry-wide Distress Affect Defaulted Firms? - Evidence from Creditor Recoveries," Journal of Financial Economics, Vol. 85 (September), pp. 787-821.

Aguiar, M., and G. Gopinath, 2005, "Fire-Sale Foreign Direct Investment and Liquidity Crises," The Review of Economics and Statistics, Vol. 87 (August), pp. 439-542.

Altman, E., B. Brady, A. Resti, and A. Sironi, 2003, "The Link between Default and Recovery Rates: Theory, Empirical Evidence and Implications," Journal of Business, Vol. 78 (November), pp. 2203-27.

Asquith, P., R. Gertner, and D. Scharfstein, 1994, "Anatomy of Financial Distress: An Examination of Junk-Bond Issuers," Quarterly Journal of Economics, Vol. 109 (August), pp. 625-58.

Bank of England, 2009, "The Role of Macroprudential Policy," A Discussion Paper (November) (Bank of England: London).

Bernanke, B.S., 2007, “The Financial Accelerator and the Credit Channel,” speech at The Credit Channel of Monetary Policy in the Twenty-first Century Conference, Federal Reserve Bank of Atlanta, Atlanta, Georgia.

Bernanke, B., and M. Gertler, 1989, "Agency Costs, Net Worth, and Business Fluctuations," American Economic Review, Vol. 79 (March), pp. 14-31.

Bernanke, B., and M. Gertler, 1990, "Financial Fragility and Economic Performance," Quarterly Journal of Economics, Vol. 105 (February), pp. 87-114.

Bernanke, B., M. Gertler, and S. Gilchrist, 1999, "The Financial Accelerator in a Quantitative Business Cycle Framework," Handbook of Macroeconomics, eds. by Taylor, J., and M. Woodford (North-Holland Elsevier Press: Amsterdam).

Bris, A., I. Welch, and N. Zhu, 2006, "The Costs of Bankruptcy: Chapter 7 Liquidation versus Chapter 11 Reorganization,” Journal of Finance, Vol. 61 (June), pp. 1253-1303.

Bruche, M., and C. Gonzalez-Aguado, 2006, "Recovery Rates, Default Probabilities and the Credit Cycle," CEMFI Working Paper No. 0612. 
Brunnermeier, M., and others, 2009, The Fundamental Principles of Financial Regulation, Geneva Reports on the World Economy, No. 11, Preliminary Conference Draft.

Carlstrom, C.T., and T.S. Fuerst, 1997, "Agency Costs, Net Worth, and Business Fluctuations: A Computable General Equilibrium Analysis," American Economic Review, Vol. 87 (December), pp. 893-910.

Carlstrom, C.T., and T.S. Fuerst, 1998, “Agency Costs and Business Cycles,” Economic Theory, Vol. 12 (November), pp. 583-97.

Chen, N.K., 2001, "Bank Net Worth, Asset Prices, and Economic Activity," Journal of Monetary Economics, Vol. 48 (October), pp. 415-36.

Christiano, L., R. Motto, and M. Rostagno, 2008, "Shocks, Structures or Monetary Policies? The Euro Area and US after 2001," Journal of Economic Dynamics and Control, Vol. 32 (August), pp. 2476-506.

Choi, W.G., and D. Cook, 2004, "Liability Dollarization and the Bank Balance Sheet Channel," Journal of International Economics, Vol. 64 (December), pp. 247-75.

Cook, D., 2004, "Monetary Policy in Emerging Markets: Can Liability Dollarization Explain Contractionary Devaluations?" Journal of Monetary Economics, Vol. 51 (September), pp. 1155-181.

Durdu, C.B., E.G. Mendoza, and M.E. Terrones, 2009, "Precautionary Demand for Foreign Assets in Sudden Stop Economies: An Assessment of the New Mercantilism," Journal of Development Economics, Vol. 89 (July), pp. 194-209.

Fisher, I., 1933, “The Debt-Deflation Theory of Great Depressions," Econometrica, Vol. 1, pp. 337-57.

Gale, D., and M. Hellwig, 1985, “Incentive-Compatible Debt Contracts: The One-Period Problem," Review of Economic Studies, Vol. 52 (October), pp. 647-63.

Galí, J., and M. Gertler, 1999, "Inflation Dynamics: A Structural Econometric Analysis," Journal of Monetary Economics, Vol. 44 (October), pp. 195-222.

Greenwood, J., Z. Hercowitz, and G.W. Huffman, 1988, "Investment, Capacity Utilization, and the Real Business Cycle," American Economic Review, Vol. 78 (June), pp. 402-17.

Hansen, G.D., 1985, “Indivisible Labor and the Business Cycle,” Journal of Monetary Economics, Vol. 16 (November), pp. 309-27. 
Holmstrom, B., and J. Tirole, 1997, "Financial Intermediation, Loanable Funds, and the Real Sector,” Quarterly Journal of Economics, Vol. 112 (August), pp. 663-91.

Kiyotaki, N., and J. Moore, 1997, “Credit Cycles," Journal of Political Economy, Vol. 105 (April), pp. 211-48.

Krugman, Paul, 2000, "Fire-Sale FDI," Capital Flows and the Emerging Economies: Theory, Evidence, and Controversies, pp. 43-58, NBER Conference Report Series (Chicago and London: University of Chicago Press).

Mendoza, E., and K. Smith, 2006, "Quantitative Implications of a Debt-Deflation Theory of Sudden Stops and Asset Prices," Journal of International Economics, Vol. 70 (September), pp. 82-114.

Sbordone, A. M., 2002, "Prices and Unit Labor Costs: A New Test of Price Stickiness" Journal of Monetary Economics, Vol. 49 (March), pp. 265-92.

Taylor, John B., 1993, "Discretion versus Policy Rules in Practice," Carnegie-Rochester Conference Series on Public Policy, Vol. 39 (December), pp. 195-214.

Shleifer, A., and R. Vishny, 1992, "Liquidation Values and Debt Capacity: A Market Equilibrium Approach,” Journal of Finance, Vol. 47 (September), pp. 1343-66.

Williamson, S.D., 1987, "Financial Intermediation, Business Failures, and Real Business Cycles," Journal of Political Economy, Vol. 95 (December), pp. 1196-216. 